\title{
ПРОБЛЕМЫ ВЗАИМОДЕЙСТВИЯ СО СТЕЙКХОЛДЕРАМИ ПРИ РЕАЛИЗАЦИИ ДОЛГОСРОЧНЫХ ГОРНЫХ ПРОЕКТОВ
}

\author{
И.ДЖОНЕК-КОВАЛЬСКА ${ }^{1}$, Т.В.ПОНОМАРЕНКО ${ }^{2}$, О.А.МАРИНИНА ${ }^{2}$ \\ ${ }^{1}$ Силезский технический университет, г. Гливице, Польша \\ ${ }^{2}$ Санкт-Петербургский горный университет, Санкт-Петербург, Россия
}

\begin{abstract}
Поскольку проекты освоения месторождений имеют долгосрочный характер, деятельность горных компаний тесно связана с развитием регионов их присутствия. Основными внешними стейкхолдерами в долгосрочных горных проектах являются местное население, органы государственной власти различного уровня и местного самоуправления. В России горные проекты реализуются как на промышленно развитых территориях, так и в регионах нового освоения, поэтому интересы и степень влияния стейкхолдеров различаются.

В европейских странах действующие горные компании ведуг деятельность в районах с высоким уровнем урбанизации, оказывая значительное влияние на качество жизни населения и развитие регионов. Кроме того, одним из ключевых отраслевых стейкхолдеров при реализации горных проектов является Европейский союз.

В статье выявлены характерные особенности и условия взаимодействия инициаторов долгосрочных горных проектов с различными категориями стейкхолдеров. Проанализированы модели идентификации, классификации и управления заинтересованными сторонами, обоснованы подходы к анализу характера взаимодействия стейкхолдеров при реализации проектов в минерально-сырьевом секторе.

С целью определения степени влияния, интереса власти и идентификации категорических групп заинтересованных сторон в долгосрочных горных проектах построены матрицы классификации стейкхолдеров в проектах строительства Элегестского и Томинского ГОКов. Доказано, что эффективное взаимодействие со стейкхолдерами определяет возможности своевременной реализации горных проектов и увеличения ценности компании.

Ключевые слова: горный проект; стейкхолдер; матрица классификации стейкхолдеров; взаимодействие; влияние; территории присутствия
\end{abstract}

Как цитировать эту статью: Джонек-Ковальска И. Проблемы взаимодействия со стейкхолдерами при реализации долгосрочных горных проектов / И.Джонек-Ковальска, Т.В.Пономаренко, О.А.Маринина // Записки Горного института. 2018. Т. 232. С. 428-437. DOI: 10.31897/PMI.2018.4.428

Введение. Разработка месторождений, включая строительство горных предприятий, обогатительных производств и других объектов, необходимых для добычи и переработки минеральносырьевых ресурсов, оказывает значительное влияние на население территорий присутствия и развитие отраслей, регионов и страны в целом. Проекты освоения месторождения являются долгосрочными, поскольку сроки их реализации оцениваются в 15-50 лет (для угля, железорудного, химического сырья - более 50 лет), объемы годовой добычи составляют десятки миллионов тонн, инвестиционные затраты - миллиарды долларов.

В связи с долгосрочным характером проектов освоения месторождений деятельность горных компаний тесно связана с развитием регионов их присутствия. В условиях глобализации транснациональные компании реализуют проекты за рубежом, взаимодействуя с населением территорий присутствия, региональными властями за рубежом, международными общественными организациями и другими заинтересованными сторонами. Неблагоприятная ценовая конъюнктура на сырьевых рынках заставляет многие компании снижать расходы на социальные программы, ориентированные на местное население, и менее активно участвовать в развитии региона (например, развитие транспортной и социальной инфраструктуры, экологическая безопасность, кооперация с малым местным бизнесом). От того, насколько эффективно взаимодействие горных компаний с органами власти и населением, зависит получение «социальной лицензии» для текущей деятельности или освоения новых месторождений.

Постановка проблемы. Ежегодно в минерально-сырьевом секторе России образуется более 4 млрд т отходов производства и потребления, основную часть которых (свыше 90 \%) составляют хвосты, связанные с добычей полезных ископаемых. При этом перерабатывается только половина отходов, остальные размещаются в виде техногенных объектов или захораниваются, накапливаясь в окружающей среде [18], что создает техногенные угрозы для населения и региона.

На горных предприятиях с подземными работами, которые являются потенциально опасными объектами, аварии могут оказать воздействие на население, на другие предприятия (объекты), 
а также на окружающую среду. Есть примеры, когда добыча минерального сырья сопровождается катастрофическими последствиями, связанными с недостаточно изученными геологическими аномалиями строения месторождений, случайным сочетанием природных и техногенных факторов, ошибками при проектировании горных работ и эксплуатации месторождений. Например, аварии, связанные со взрывами угольной пыли и подземными пожарами, происходили на угольных шахтах Китая, Польши, России, Индии; с водо- и рассолопритоками - на калийных рудниках Канады, Германии и России [4].

Таким образом, современная горная компания должна демонстрировать обоснованный подход к разработке масштабных проектов с пристальным вниманием к социальным и экологическим вопросам и иметь представление о масштабах своего финансового участия в процессе удовлетворения изменяющихся со временем потребностей стейкхолдеров. Такая проактивная стратегия взаимодействия со стейкхолдерами определяет возможности своевременной реализации проекта и увеличения ценности компании. Основными внешними стейкхолдерами в горных проектах являются местное население, органы государственной власти различного уровня и местного самоуправления.

Взаимодействие с местным населением на территориях присутствия. Несмотря на привлечение в регионы значительных инвестиций, налоговые поступления в бюджеты, создание новых рабочих мест, горные компании часто сталкиваются с противодействием местного населения. Например, проекты строительства Томинского ГОКа (Россия), Рошия-Монтанэ (Румыния), Tia Maria (Перу) не получили одобрения местного сообщества ввиду недостаточного внимания к экологическим вопросам. Закрытие проекта «Эльдорадо» (Греция) вследствие нарушения компанией финансовых и природоохранных обязательств вызвало сопротивление шахтеров и местных правозащитников. В 2015 г. правительство Монголии одобрило дальнейшую разработку месторождения Oyu Tolgoi после общенационального референдума.

В некоторых странах (Финляндия, Перу, Монголия, Индия) получение согласия местных жителей является неотъемлемой процедурой официального процесса выдачи разрешений на недропользование. Местные власти имеют значительное влияние на утверждение проектов в вопросах коммерческого использования земель, справедливого вознаграждения за пользование недрами и сохранения историко-культурного наследия регионов. Например, шестилетнее согласование крупного проекта строительства медного рудника Las Bambas в Перу завершилось только после принятия оператором социальных обязательств по строительству коттеджного поселка, инженерных коммуникаций и инфраструктуры для местных жителей. По решению суда компания Vedanta отказалась от проекта разработки рудника с инвестициями в 2 млрд долларов вблизи гор Ньямгири в индийском штате Орисса - объекта культового поклонения местных племен. Путем многолетних переговоров с мелкими предприятиями и местным населением получены «социальные лицензии» для работы на золоторудных месторождениях Minas Conga (Перу) и North Mara (Танзания) [6].

Предоставление лицензий в российской практике осуществляется через государственную систему лицензирования (Постановление ВС РФ от 15.07.1992 N 3314-1 (ред. от 05.04.2016) «О порядке введения в действие Положения о порядке лицензирования пользования недрами». Система ГАРАНТ. URL http://base.garant.ru/12120191/\#ixzz52UYd1fsE (дата обращения 07.12.2017)), при этом при разработке декларации о намерениях и предынвестиционного технико-экономического обоснования (ТЭО) и технико-экономических расчетов (ТЭР), рабочего проекта, согласно законодательству о местном самоуправлении и экологической экспертизе (Федеральный закон от 23 ноября 1995 года № 174-Ф3 «Об экологической экспертизе». Система ГАРАHT. URL: http://base.garant.ru/12120191/\# ixzz52UYd1fsE (дата обращения 07.12.2017)), должны быть проведены общественные слушания. Их целью является информирование общественности о намечаемой хозяйственной деятельности и ее возможном воздействии на окружающую среду (ОВОС), выявление общественных предпочтений и их учет в процессе оценки воздействия. Проведение слушаний и согласование с органами власти является отдельной стадией в процедуре ОВОС, предшествующей выработке окончательного варианта «Материалов оценки воздействия» (Приказ Госкомэкологии РФ от 16 мая 2000 г. N 372 «Об утверждении Положения об оценке воздействия намечаемой хозяйственной и иной деятельности на окружающую среду в Российской Федерации». Система ГАРAHT. URL: http://base.garant.ru/12120191/\# ixzz52UYd1fsE (дата обращения 07.12.2017) для различных этапов обоснования и реализации проектов освоения месторождений. 
Интересным примером европейского опыта функционирования горной промышленности является угольная отрасль Польши. Основным угольным бассейном в стране является Верхнесилезский, где работают компании Polska Grupa Górnicza и Jastrzębska Spółka Węglowa, a также несколько частных шахт. В Люблинском угольном бассейне работает одна шахта. Действующие горные компании, находящиеся в районах с высоким уровнем урбанизации, оказывают значительное влияние на качество жизни населения и развитие регионов. В 1990 -е годы в Силезском воеводстве $20 \%$ трудоспособного населения работало в угольной промышленности (400 тыс. чел). В настоящее время их число сократилось до $5 \%$ (100 тыс. чел.), но угольная промышленность по-прежнему остается важнейшей отраслью в регионе.

Особую угрозу для безопасности труда представляют выбросы метана [9]. К примеру, у компании Węglowa в 2015 г. на пяти из 12 действующих угольных шахт глубина добычи превышала 900 м. С 1990 г. при шести несчастных случаях на этих шахтах погибло 77 горняков. По критическим показателям уровня метаноопасности и горных ударов в 2017 г. шахты были закрыты.

Взаимодействие с государством. Объектом горной промышленности являются участки недр (месторождения), являющиеся собственностью общества (государства), поэтому эффективность горного производства должна отражать согласованные интересы общества, государства и недропользователя. В настоящее время во всем мире отмечается тенденция к росту налогов и роялти. Некоторые развивающиеся страны (Индия, Гватемала, Демократическая Республика Конго) изменяют налоговые режимы с целью повышения государственных доходов. Однако для привлечения частных инвесторов в горную отрасль и снижения риска выведения активов из страны ряд ресурсодобывающих стран (Перу, Монголия, Эквадор) пересмотрел нормативноправовые акты в пользу недропользователя. Правительство Австралии в 2014 г. отменило рентный налог на добычу угля и железной руды, а власти Замбии снизили ставки роялти для поддержания компаний и сохранения рабочих мест [5].

Другим способом увеличения доходов государства является применение принципа обязательного обогащения минерального сырья, который нацелен на стимулирование производства продукции с более высокой добавленной стоимостью. Например, в Индонезии действует запрет на экспорт необогащенного никеля, бокситов и меди, в Намибии функционирует комитет по стимулированию выпуска продукции более высоких переделов, в Зимбабве, ЮАР, Гане горно-металлургические компании включены в план правительства по обязательному обогащению платиновых руд.

В Польше государству принадлежит большая часть горнодобывающих предприятий, поэтому оно является важным стейкхолдером для них. Только две из действующих угольных шахт являются частными с долей рынка менее $1 \%$. Компания Polska Grupa Górnicza является государственной, а компании Jastrzębska Spółka Węglowa и LW Bogdanka - акционерные общества, зарегистрированные на Варшавской фондовой бирже, с преобладающим участием государства в капитале. Поэтому государство заинтересовано в экономических результатах и энергетической безопасности страны, при этом ограничено законодательством ЕС [22], т.е. эти задачи являются внутренне противоречивыми. В настоящее время правительство придерживается политики экономической независимости, создания и сохранения рабочих мест и использования собственных источников энергии. Можно предположить, что такая политика будет сохраняться в ближайшие годы. Опираясь на вышеперечисленные приоритеты, правительство ведет переговоры с ЕС об ограничении выбросов углекислого газа в Польше. Однако в 2017 г. эти переговоры потерпели неудачу, и Польша получила лишь финансовую поддержку для модернизации энергетической инфраструктуры.

В Польше горное дело подлежит лицензированию: разрешение на начало добычи выдается государством по результатам ТЭО по добыче полезного ископаемого [23]. Для получения лицензии необходимо утверждение отчета об окружающей среде, получение разрешения местных органов власти на начало разработки месторождения или одобрение плана работы горнодобывающего предприятия на уже существующем руднике. Такие же согласования требуются и при разработке нового пласта, и при строительстве новой угольной шахты. Случаются отказы в выдаче лицензии (в 2017 г. австралийской компании было отказано в разрешении на добычу угля в Люблинском угольном бассейне из-за отсутствия одобрения экологического отчета) и местных сообществ (община отклонила план эксплуатации шахты в Sośnica-Makoszowy). Без положительного решения угольная шахта не может быть введена в эксплуатацию. 
Протесты экологического характера проходят редко, что связано с систематическим проведением восстановительных мероприятий на территориях, нарушенных горными работами, а также устранением и компенсацией причиненных ущербов. Польские горнодобывающие предприятия обязаны отчислять взносы в ликвидационный фонд. Часть финансовых обязательств, связанных с процессом ликвидации шахт и последствий горного производства, берет на себя государство, покрывая около 60 \% долгосрочных последствий от ликвидации угольных шахт [16].

Положения ЕС, касающиеся выбросов двуокиси углерода, фактически стали причиной прекращения добычи каменного угля практически во всем Европейском союзе, за исключением Польши (2020 Climate \& Energy Package, European Union strategic document. URL: https://ec.europa.eu/clima/ policies/strategies/2020_en). Эти нормы не предусматривали государственного субсидирования каменноугольных шахт, что значительно ограничивало возможности развития польской каменноугольной промышленности и реализации горных проектов. Направления государственного финансирования для добычи каменного угля были ограничены решением Европейской комиссии по государственной помощи для содействия закрытию неконкурентоспособных угольных шахт (Decision of the European Commission on state aid to facilitate the closure of uncompetitive coal mines (2010/787/UE. URL: https://ec.europa.eu/clima/policies/strategies/2020_en). Согласно документу, в настоящее время государственная помощь предоставляется только по двум направлениям. Во-первых, до 31 декабря 2018 г. на расходы по закрытию нерентабельных шахт, включая текущие производственные расходы. Во-вторых, на чрезвычайные расходы, финансируемые до конца 2026 г., которые связаны с социальными (пенсии и пособия по увольнению) и техническими (обеспечение инфраструктуры ликвидируемых шахт) затратами. Таким образом, финансовая поддержка ликвидируемых шахт в Польше возможна даже после их закрытия. В европейских странах Европейский союз является стейкхолдером с ключевым отраслевым значением для реализации стратегических горных проектов [10]. Это обстоятельство расширяет традиционно признанные и идентифицированные в литературе группы стейхколдеров и дополнительно усложняет и без того сложные взаимоотношения с горнодобывающим сектором.

Гипотеза. Значительная часть стейкхолдеров (население региона присутствия, федеральные и региональные власти) долгосрочных горных проектов имеют высокую степень интереса, влияния и власти. Степень влияния стейкхолдеров зависит от типа проекта и региона освоения месторождения.

Рассмотрим вопросы:

1) каким образом классифицируются стейкхолдеры долгосрочных горных проектов по типу интереса, влияния и власти;

2) существуют ли отличия в классификации заинтересованных сторон горных проектов, peализуемых в регионах нового освоения и на промышленно развитых территориях.

Результаты исследования базируются на общенаучных методах анализа, синтеза, качественной и количественной оценке.

Обзор литературы. В современном менеджменте проблемы управления взаимодействия со стейкхолдерами исследуются на основе теории заинтересованных сторон [7]. В исследованиях Дж.Поста, Л.Престона и С.Сакс подчеркнута важность отношений со стейкхолдерами, особенно для сложных «расширенных предприятий» (корпораций), которые становятся «важнейшим активом и конечным источником организационного богатства». Основой теории является положение о том, что цели компании гораздо шире, чем создание богатства для ее собственников, и включают заботу о благосостоянии гораздо более широкого круга заинтересованных сторон [3]:

- корпорация имеет отношения с большим количеством групп и индивидов (стейкхолдеров), составляющих ее окружение (внутреннее и внешнее);

- необходимо исследование природы этих отношений как процессов (сопровождающих отношения) и результатов (ресурсного обмена) для компании и ее стейкхолдеров;

- интересы всех стейкхолдеров потенциально могут быть приняты во внимание и удовлетворены путем принятия управленческого решения.

При различных оценках степени положительного влияния корпоративной социальной ответственности (КСО) на эффективность развития бизнеса доказано, что безответственное поведение негативно влияет на бизнес $[13,20]$, а также, что существует устойчивая связь между социальной ответственностью компании, сфокусированной на взаимодействии с работниками и потребителями, и финансовыми результатами $[2,8,19]$. 
Подходы к анализу отношений фирмы и ее заинтересованных сторон, выявление факторов, определяющих характер взаимодействия стейкхолдеров, их идентификация и способы управления рассматривались в работах Т.Джонсона, Ш.Бермана, А.Викса, С.Кота, М.Дженсона, А.Маквильямса и Д.Зигеля, С.Бреннера и П.Кохрена, Р.Митчела, Б.Эгла и Д.Вуда [2].

Наиболее известными и часто используемыми методами для сопоставления заинтересованных сторон являются: классификация стейкхолдеров по признакам власти, легитимности и срочности [17], ожиданиям и относительной значимости [11], потенциальной угрозы и потенциала для сотрудничества [21], оценки осведомленности, поддержки, влияния, удовлетворенности [24], сопоставления ожиданий стейкхолдеров на основе иерархии ценностей и ключевых областей эффективности [14].

К методам анализа стейкхолдеров относят трехмерную группировку по признакам власти, интереса и отношения (модель Митчелла-Агла-Вудда), матрицы «власти - интереса» [15], «влияния - воздействия», «влияния - интереса».

В модели Митчелла-Агла-Вудда выделяют семь классов значимости стейкхолдеров. Три из них обладают одним атрибутом - «латентные», три - двумя («ожидающие») и один - тремя («категорическая» группа).

К «латентным» группам относятся «бездействующая» или «спящая» (обладает властью), «контролируемая» (обладает законностью) и «требующая» (обладает срочностью). «Ожидающие» группы, в свою очередь, состоят из «доминирующей» (власть и законность), «зависимой» (законность и срочность) и «опасной» (власть и срочность) групп. Самой влиятельной группой являются «категорические» стейкхолдеры, обладающие одновременно тремя атрибутами . Данную группу заинтересованных сторон следует отнести к ключевым стейкхолдерам - выстраивание политик взаимоотношения с ними требует самого тщательного подхода $[1,17]$.

Концепция КСО реализуется как в текущей, так и проектной деятельности горной компании. Дж.Р.Тернер [24] подчеркнул, что потребность в выявлении заинтересованных сторон проекта обусловлена тем, что успех проекта заключается в согласовании критериев успеха со всеми стейкхолдерами еще на этапе инициации.

А.Менделоу [15] предложила использовать для систематизации заинтересованных сторон матрицу (в дальнейшем «матрица Менделоу»), напоминающую матрицу SWOT-анализа, где стейкхолдеры распределяются по уровню полномочий и заинтересованности в реализации проекта. В матрицах анализа стейкхолдеров под властью понимается уровень полномочий, под интересом - уровень заинтересованности в результатах проекта, под влиянием - уровень участия в проекте, под воздействием - способность вносить изменения в проект.

Методика исследования. Основные группы стейкхолдеров проектов «Томинский ГОК» и «Элегестский ГОК» определены по упрощенному перечню заинтересованных сторон Э. Фримена $[2,12]$ и включают в себя собственников $(\mathrm{A})$, федеральные власти $(\mathrm{F})$, региональные власти $(\mathrm{H})$, инвесторов $(\mathrm{L})$, работников $(\mathrm{D})$, поставщиков $(\mathrm{E})$, покупателей $(\mathrm{G})$, конкурентов $(\mathrm{Z})$, население регионов присутствия (I), руководителя проекта (B), команду проекта $(\mathrm{C})$, средства массовой информации (М), учащихся профильных учебных заведений (K).

Для ранжирования обозначенных групп в исследовании используются матрицы Мендлоу (власти и интереса) и Office of Government Commerce (влияния и воздействия). Для классификации и ранжирования заинтересованных сторон проектов разработана специальная анкета. Вопросы составлены по типу закрытого анкетирования, используется шкала от 1 до 5, определяющая степень интереса, влияния и власти на проект заинтересованных сторон. Для повышения уровня отклика к анкете прилагалось информационное письмо, объясняющее цели опроса. Содержание анкеты дополнительно тестировали на валидность пять опытных исследователей в области проектного управления, которые оценили ее с точки зрения определенности, четкости и адекватности формулировок и использованной терминологии. Полученные комментарии стали основой для корректировки анкеты.

Репрезентативность анкетирования обеспечена формированием целевой выборки респондентов из числа специалистов в области горного дела, экологов, экономистов и специалистов по обоснованию проектов проектных организаций (ООО «Гипрошахт», АО «Гипроруда», ООО «Институт Гипроникель», ООО «Полиметалл»). В течение трех месяцев отклик составил $40 \%$ (из 200 разосланных анкет получены 80 заполненных). 
Проблемы взаимодействия со стейкхолдерами..

Результаты. Исходные данные по проектам Томинского ГОКа (староосвоенный, промышленно развитый район) и Элегестского ГОКа (новый район освоения) представлены в таблице.

Характеристика стратегических проектов освоения Томинского и Элегестского месторождений

\begin{tabular}{l|l|c|c|c}
\hline \multicolumn{1}{c|}{ Месторождение } & \multicolumn{1}{c|}{ Инвестор } & $\begin{array}{c}\text { Размер } \\
\text { инвестиций, } \\
\text { млрд долларов }\end{array}$ & $\begin{array}{c}\text { Годовая } \\
\text { производственная } \\
\text { мощность } \\
\text { по добыче, млн т }\end{array}$ & $\begin{array}{c}\text { Срок реализации } \\
\text { проекта, годы }\end{array}$ \\
\hline $\begin{array}{l}\text { Элегестское угольное месторож- } \\
\text { дение, Республика Тыва }\end{array}$ & $\begin{array}{l}\text { ЗАО «Тувинская энерге- } \\
\text { тическая промышленная } \\
\text { компания» } \\
\text { ПАО «Русская медная } \\
\text { Компания» }\end{array}$ & 3,6 & 15 & $2013-2032$ \\
$\begin{array}{l}\text { Томинское медно-порфировых Челябинская обл. } \\
\text { руд, }\end{array}$ & 1,3 & 28 & $2017-2043$ \\
\end{tabular}

Анализ данных анкетирования на основе классификации стейкхолдеров по признакам власти, легитимности и срочности [17] графически представлен на рис.1.

Конкуренты, средства массовой информации (СМИ) и учащиеся профильных учебных заведений являются латентными стейкхолдерами и не требуют управления. Работники и население регионов присутствия относятся к ожидающим стейкхолдерам на осваиваемых территориях, к категорическим - в старопромышленных регионах. Собственники, федеральные власти, региональные власти, инвесторы, работники, поставщики, покупатели, конкуренты, руководители проекта, команда проекта являются категорическими стейкхолдерами. Именно на них компании необходимо сконцентрировать свое внимание при управлении проектом. Интересы этих групп стейкхолдеров должны удовлетворяться, финансовые и нефинансовые результаты проекта должны открыто публиковаться компанией в отчетах об устойчивом развитии для информирования стейкхолдеров о проведенной работе.

После обработки анкет построены матрицы, определяющие степень влияния, интереса и власти в проектах (рис.2).

Обсуждение. На основе анализа заинтересованных сторон (3С) разрабатывается стратегия взаимодействия с ними. Взаимодействие с ЗС включает: оценку власти и интереса ЗС; оценку влияния и воздействия 3С; разработку подходов к взаимодействию с 3 .

Анализ власти и заинтересованности проектов освоения Томинского и Элегестского месторождений (рис.2) показал, что наивысший уровень власти и интереса присущ государству (для федерального и регионального уровня в равной степени). Поэтому государство может оказать
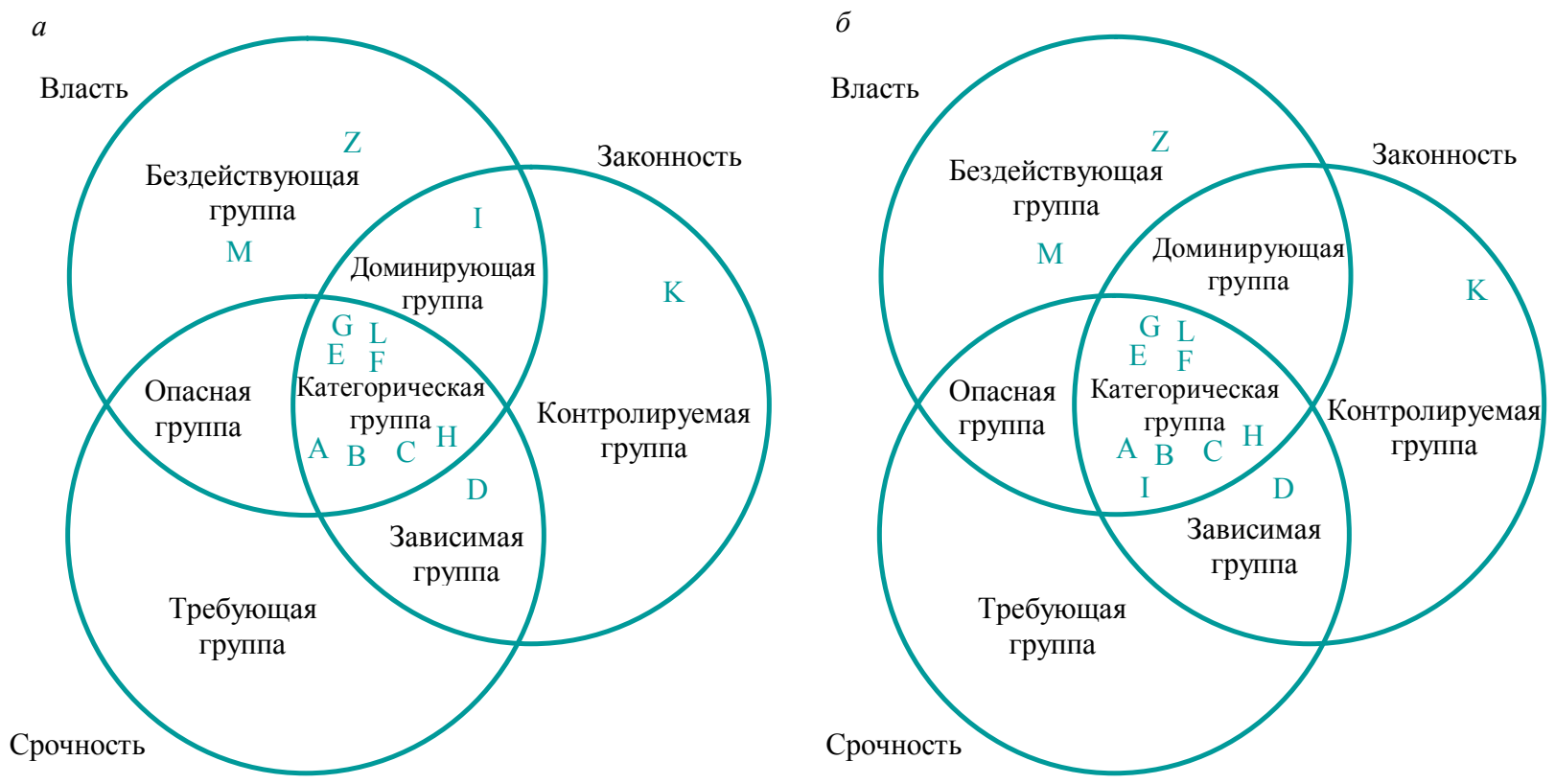

Рис.1. Классификация заинтересованных сторон проектов «Элегестский ГОК» $(a)$ и «Томинский ГОК» (б) 

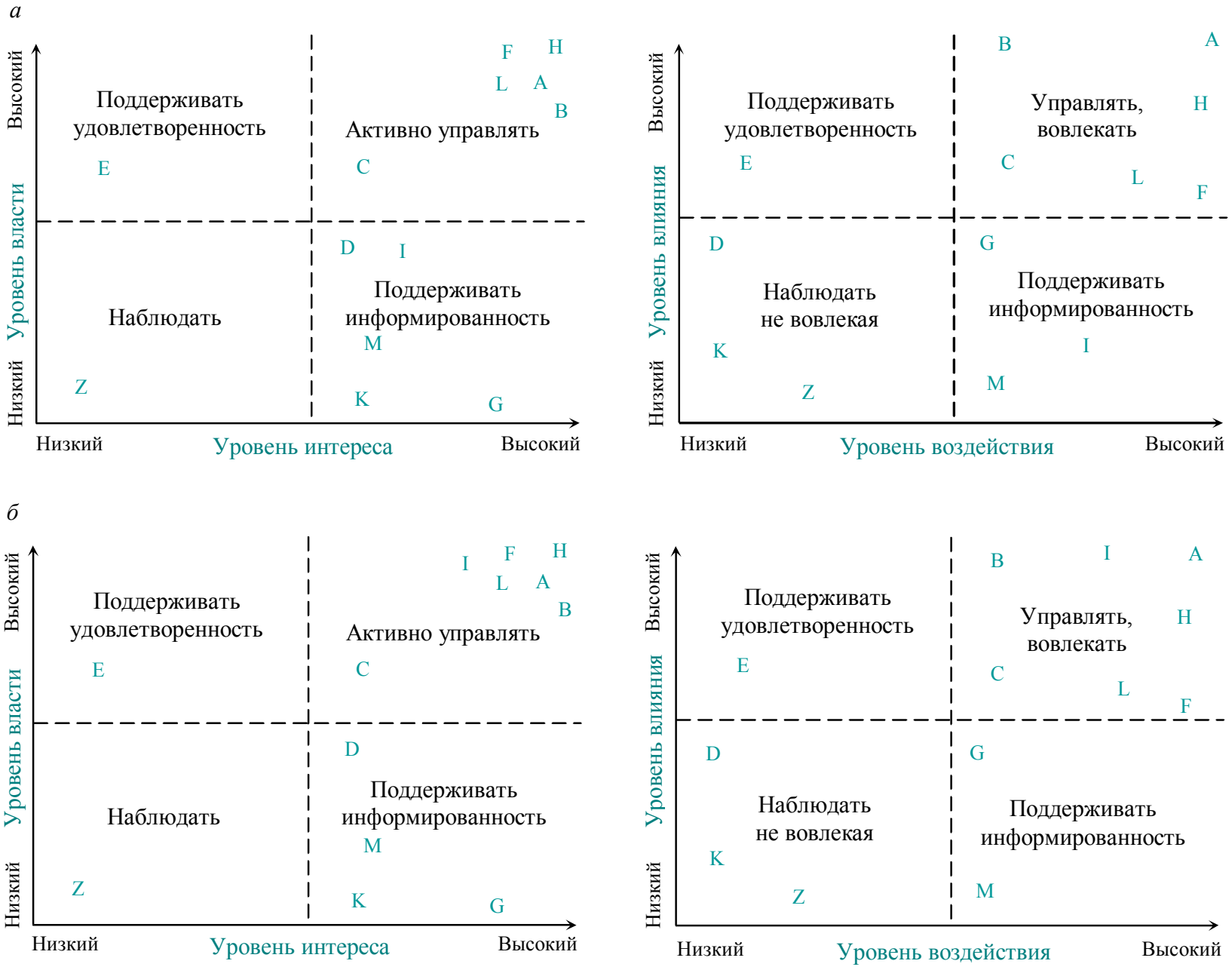

Рис 2. Матрицы классификации стейкхолдеров проектов «Элегестский ГОК» $(a)$ и «Томинский ГОК» (б)

государственную поддержку проектам в различной форме. Далее ключевыми заинтересованными сторонами выступают акционеры, частные инвесторы, руководитель и команда проекта, интересы и власть которых имеют высокую значимость, ввиду их непосредственной вовлеченности в проект. Вышеперечисленные группы ЗС могут способствовать оптимизации расходов, влиять на изменение содержания, сроков реализации, начала проектов, его качества и стоимости.

Проект «Томинский ГОК» включен в «Стратегию развития цветной металлургии России на 2014-2020 годы и на перспективу до 2030 года». Общая сумма налогов за время работы ГОКа составит порядка 120 млрд руб, будет создано 1200 рабочих мест. Помимо этого Томинский ГОК даст мультипликативный эффект для экономики региона: заказы для строительных организаций, трубопрокатных и машиностроительных заводов, создание инфраструктуры. По расчетам экспертов, на одно рабочее место на предприятии придется 3-7 дополнительных рабочих мест (см. «Более половины южноуральцев высказались против строительства Томинского ГОК». URL: http://www.nakanune.ru/news/2016/2/10/22427363 (дата обращения 05.02.2018)).

Участие государства в Элегестском проекте будет реализовано в форме государственночастного партнерства (ГЧП). В настоящее время правительством РФ утвержден проект строительства железной дороги Кызыл - Курагино к месторождению Элегест (бюджет 192,4 млрд руб.), где главным инвестором на концессионной основе является Тувинская энергетическая промышленная компания (ТЭПК). Обязательным условием данного договора для ТЭПК является необходимость параллельной реализации проекта строительства Элегестского ГОКа. Бюджетная эффективность проекта отработки месторождения за период 2017-2032 годов составит более 10 млрд руб. Проектом «Элегестский ГОК» предусмотрено инвестирование в размере 3,5 млрд руб. в строительство социальной инфраструктуры (жилые дома, детские сады, общеобразовательные школы, магазины, 
склады, предприятия общественного питания, бани, химчистка и клуб) (см. «Глава Тувы: актуальность проекта «Кызыл-Курагино» с каждым годом только повышается». URL: http://tass.ru/novosti-partnerov/4805487 (дата обращения 05.02.2018)).

Этап идентификации «силы» и «интереса» группы «Население региона присутствия» выявил различие в их влиянии на условия реализации проектов для староосвоенного и нового региона. Поскольку Элегестское месторождение планируется осваивать на территории неразвитого в промышленном отношении региона, местное население имеет среднюю степень влияния и высокую заинтересованность. В случае реализации проекта «Томинский ГОК» на территории высокоурбанизированной промышленно развитой Челябинской области местное население имеет чрезвычайно высокую степень влияния и высокую заинтересованность.

Несмотря на положительные экономические и социальные результаты реализации проекта «Томинский ГОК» в виде отчислений в бюджеты разных уровней и создания новых рабочих мест в регионе, 51 \% жителей Челябинской области негативно относятся к реализации проекта, опасаясь негативных экологических последствий добычи и металлургического передела меди. После общественных слушаний инвестором проекта «Русской медной компанией» внесены значительные изменения в проект, включая отказ от гидрометаллургического производства и размещения хвостов в Коркинском разрезе; усилена социально-экологическая направленность проекта, проведены дополнительные экспертизы и привлечено академическое сообщество, однако жителям региона удалось заблокировать проект. Местное население потенциально попадает под воздействие негативных факторов, поэтому является наиболее уязвимым и требует первоочередного взаимодействия с инвесторами.

Поставщики в обоих проектах обладают средним уровнем власти и заинтересованности, так как отработка угольного Элегестского и рудного Томинского месторождений планируется с применением известных технологий без использования уникального оборудования.

Ранжирование групп «работники», «конкуренты», «покупатели», «СМИ» и «учащиеся профильных учебных заведений» показывает низкую степень показателей «влияния и заинтересованности» в проектах. Интерес СМИ является профессиональным, не превышающим интерес к любым другим событиям в стране, однако взаимодействие СМИ и местного населения представляет собой значительный фактор влияния, что требует постоянной работы по информированию групп ЗС о проекте.

Результаты классификации на основании матрицы «влияния и воздействия» свидетельствуют, что наиболее влиятельными группами стейкхолдеров с максимальным уровнем воздействия являются акционеры, далее - руководители проекта, региональные и федеральные власти, инвесторы, по отношению к которым необходимы пристальный контроль и вовлечение их в реализацию проекта.

К группе с высоким уровнем влияния и низким уровнем воздействия относятся поставщики. Последовательное взаимодействие с поставщиками на стадиях закупки, строительства, эксплуатации может оказать эффективную помощь в анализе проблем и результатов.

К группе с низким уровнем влияния и высоким уровнем воздействия относятся работники, покупатели и средства массовой информации. Данные группы требуют сохранения удовлетворенности при регулярном информировании. Группы с низким уровнем влияния и интереса - конкуренты и учащиеся профильных учебных заведений, нуждаются в мониторинге на этапе инициации проекта.

Исходя из результатов анализа матриц заинтересованных сторон, можно сделать выводы о том, что контролировать и активно вовлекать в проект следует органы государственной власти, акционеров, инвесторов, руководителя и команду проекта. Работников, покупателей и учащихся профильных учебных заведений и СМИ необходимо информировать об изменениях в проекте. Интересы поставщиков необходимо удовлетворять, за конкурентами - наблюдать.

Особое внимание следует обратить на группу «местное население», степень влияния и воздействия которой меняется в зависимости от фактора - регион присутствия. В проекте «Томинский ГОК» местное население имеет высокую степень влияния и воздействия, в проекте «Элегестский ГОК» население имеет среднюю степень влияния и высокую степень воздействия.

С целью исключения конфликтов с местным населением проекта «Элегестский ГОК» необходимо изучить быт, обычаи и верования коренного населения Тывы. Перед началом реализации проекта необходимо убедиться, что на территории строительства отсутствуют предметы, относящиеся к 
археологическому наследию республики. Недостаточно ответственное отношение к этим проблемам уже приводило к остановке строительства железной дороги в 2007 г.

При разработке подхода к управлению отношениями с ЗС следует учитывать, что для современных крупных горных компаний характерен переход от компенсации негативных воздействий и реагирования на запросы стейкхолдеров к активному управлению, воздействию и влиянию на их интересы. Стратегия управления учитывает согласование интересов заинтересованных сторон и строится на интенсивном взаимодействии с ключевыми стейкхолдерами.

Согласно международным стандартам по социальной ответственности AА1000, вовлеченность как один из ведущих принципов предполагает участие стейкхолдеров в принятии стратегических решений в целях устойчивого развития (AA1000 Principles Standard. URL: http://www.accountability.org/standards/aa1000aps.html (дата обращения 07.12.2017)). Поэтому горная компания не только должна своевременно отслеживать и реагировать на наиболее разумные и обоснованные требования, предъявляемые стейкхолдерами в отношении контроля, но и предоставить им возможность непосредственного участия в контрольных процедурах, высказывая свои предложения и замечания (например, посредством фокус-групп, семинаров, консультационных групп и т.д.).

Заключение. Идентификация, планирование управления, управление вовлеченностью заинтересованных сторон осуществляется непрерывно в течение всего жизненного цикла проекта освоения месторождения. Процесс управления динамичен и вариативен в зависимости от условий и особенностей каждого проекта.

Горнодобывающие компании взаимодействуют с несколькими ключевыми заинтересованными сторонами, которые влияют на реализацию стратегических проектов.

Конфликт интересов заинтересованных сторон связан с тем, что интересы каждой конкретной заинтересованной стороны не соответствуют требованию максимизации общих экономических выгод.

В ходе исследования долгосрочных горных проектов были выявлены следующие интересы стейкхолдеров:

- федеральные власти - необходимость соблюдения жестких законодательных требований в части комплексного и рационального использования минеральных ресурсов и промышленной безопасности;

- региональные власти - необходимость соблюдения законодательных требований, касающихся окружающей среды и строительства объектов;

- местное население - охрана окружающей среды, создание рабочих мест;

- инвесторы - необходимость развития инфраструктуры, создание новых возможностей для развития;

- Европейская комиссия (для стран участников ЕС) - соблюдение требований стандартов и правил Европейского союза.

Были проанализированы модели управления заинтересованными сторонами, включая: трехмерные группировки по признакам власти, интереса и отношения (модель Митчелла-АглаВудда), матрицы «власти - интереса», «влияния - воздействия».

Заинтересованные стороны были классифицированы на скрытые, ожидающие и категорические. Большинство заинтересованных сторон проектов «Томинский ГОК» и «Элегестский ГОК» (федеральные и региональные органы власти, акционеры, инвесторы, поставщики, покупатели) идентифицированы как категорические. Интересы этих групп стейкхолдеров должны учитываться и удовлетворяться при разработке окончательного варианта оценки воздействия на окружающую среду на этапах подачи декларации о намерениях, технико-экономического обоснования, технико-экономического расчета и рабочего проекта. На этапе отработки месторождения финансовые и нефинансовые результаты проекта должны публиковаться горной компанией в отчетах об устойчивом развитии для информирования стейкхолдеров.

Местное население для регионов нового освоения (Элегестский ГОК) идентифицировано как ожидающая заинтересованная сторона, в хорошо развитых регионах (Томинский ГОК) - как категорическая группа. Основными инструментами для взаимодействия с категорическими заинтересованными сторонами являются фокус-группы, общественные встречи, партнерские отношения, комитет по консультированию. 


\section{ЛИТЕРАТУРА}

1. Абросимова А.Б. Системный анализ стейкхолдеров / А.Б.Абросимова, И.М.Седельникова // Вестник Инжэкон. Серия «Экономика». 2011. № 3. С. 222-230.

2. Благов Ю.Е. Корпоративная социальная ответственность: эволюция концепции СПб: Изд-во «Высшая школа менеджмента», 2010. 272 c.

3. Петров М.А. Теория заинтересованных сторон: пути практического применения // Вестник СПбГУ. Сер. 8. 2004. Вып. 2 (№ 16). С. 51-68.

4. Пономаренко Т.В. Корпоративная социальная ответственность угольной отрасли (практика российских и европейских компаний) / Т.В.Пономаренко, Р.Вольник, О.А.Маринина // Записки Горного института. 2016. Т. 222. С. $882-891$. DOI: 10.18454/PMI.2016.6.882

5. Ресурсная модель модернизации экономики: возможности и ограничения / Под ред. В.Б.Кондратьева. М.: ИМЭМО PAH, 2016. $326 \mathrm{c}$.

6. Рябова Л.А. Социальная лицензия на деятельность ресурсодобывающих компаний как новый инструмент социального развития / Л.А.Рябова, В.В.Дидык // Вопросы государственного и муниципального управления. 2015. № 3. С. 61-82.

7. Тамбовцев В.Л. Стейкхолдерская теория фирмы в свете концепции режимов собственности // Российский журнал менеджмента. 2008. Т. 6. № 3. С. 3-26.

8. Третьяк O.A. Корпоративная социальная ответственность российских компаний // Российский журнал менеджмента. 2015. № 2. URL: http://www.marketing.spb.ru/mr/business/Corporate_Governance.htm (дата обращения 27.09.2016).

9. Bijańska J. Defining a strategy of coal enterprises in crisis situation / J.Bijańska, K. Wodarski // 4th BE-ci. International Conference on Business \& Economics, 05-07 June, 2017, Brno, Czech Republic. Ed. by: Zafer Bekirogullari, Melis Y. Minas \& Roslind X. Thambusamy. Brno: Future Academy. 2017. P.91-105.

10. Bluszcz A. European economies in terms of energy dependence // Quality and Quantity. 2017. Vol. 51. № 4. P. 1531-1548.

11. Cameron B.G. Goals for space exploration based on stakeholder network value considerations / B.G.Cameron, T.Seher, E.F.Crawley // Acta Astronautica. 2010. № 68 (11-12). P.2088-2097. DOI:10.1016/j.actaastro.2010.11.003

12. Freeman R.E. Stakeholder Management: A Stakeholder Approach. Marshfield, MA: Pitman Publishing, 1984. 275 p.

13. Kang K.H. Impacts of positive and negative corporate social responsibility activities on company performance in the hospitality industry / K.H.Kang, S.Lee, C.Huh // International Journal of Hospitality Management. 2010 . № 29 (1). P. 72-82.

14. Mapping stakeholder perceptions for a third sector organization / A.Fletcher, J.Guthrie, P.Steane, S.Pike // Journal of Intellectual Capital. 2003. № 4(4). P. 505-527. URL: http://ir.knust.edu.gh/bitstream/123456789/4261/1/ATIIBO \%20KENNEDY \%20AYATAH.pdf (date of access 7.12.2017).

15. Mendelow A. Stakeholder Mapping // Proceedings of the 2nd International Conference on Information Systems. Cambridge: MA, 1991. URL: http://www.termpaperwarehouse.com/essay-on/ Stakeholder-Mapping/140410 (date of access 7.12.2017).

16. Michalak A. Comparative analysis of the cost of equity of hard coal mining enterprises - an international perspective/ A.Michalak, T.Nawrocki // Gospodarka Surowcami Mineralnymi. 2015. T.31. Z. 2. P. 49-72.

17. Mitchell R.K. Toward a Theory of Stakeholder Identification and Salience: Defining the Principle of Who and What really Counts / R.K.Mitchell, B.R.Agle \& D.J.Wood //Academy of Management Review. (Oct., 1997). Vol. 22. № 4. P. 853-888.

18. Nevskaya M.A. Regulatory Aspects of Mining Waste Management in the Russian Federation / M.A.Nevskaya, O.A.Marinina // Biosci., Biotech. Res. Asia, December 2015. Vol. 12(3). P. 2619-2628. URL: http://www.biotechasia.org/vol12no3/regulatory-aspects-of-mining-waste-management-in-the-russianfederation/ (date of access 5.02.2018).

19. Ponomarenko T.V. Corporate responsibility of mining companies: Mechanisms of interaction with stakeholders in projects implementation / T.V.Ponomarenko, O.A.Marinina // Journal of Applied Economic Sciences. 2017, Vol. 12(6). P.1826-1838.

20. Relationship between Corporate Social Responsibility (CSR) and Corporate Financial Performance (CFP): literature review approach / A.Raza, M.I.Ilyas, R.Rauf, \& R.Qamar // Elixir Financ. Manag. 2014. 46. P. 8404-8409.

21. Savage G.T. Whitehead and Blair. Strategies for assessing and managing organizational stakeholders / G.T.Savage, T.W.Nix // Academy of Management Executive. 1991. № 5(2). P. 61-75.

22. Sienkiewicz-Matyjurek K. Impact of climate changes on the European industry // Metalurgija. 2014. Vol. 53. Iss. 2. P. $254-256$.

23. Turek M. Techniczno-organizacyjne aspekty zgazowywania węgla w podziemiach czynnej kopalni, na przykładzie eksperymentu przeprowadzonego w kopalni Wieczorek // Przemysł Chemiczny. 2015. Vol. 94. № 6. P. 1012-1017.

24. Turner J.R. The project manager as change agent / J.R.Turner, V.Kristoffer \& L.Thurloway. London: McGraw-Hill Pablishing Co, 2002. $264 \mathrm{p}$.

Aвторы: И. Джонек-Ковальска, д-р экон. наук, професcop, izabela.jonek-kowalska@polsl.pl (Силезский технический университет, г. Гливице, Польша), Т.В.Пономаренко, д-р экон. наук, профессор, stv_mail@таil.ru (Санкт-Петербургский горный университет, Санкт-Петербург, Россия), О.А.Маринина, канд. экон. наук, доцент, тоа95@yаndex.ru (СанктПетербургский горный университет, Санкт-Петербург, Россия).

Статья поступила в редакиию 12.02.2018.

Статья принята к публикачии 30.05.2018. 